\title{
Electronic Module Development with Project Based Learning in Web Programming Courses
}

\author{
$1^{\text {st }}$ Agus Prasetya \\ ${ }^{1}$ Institut Teknologi Bisnis AAS Indonesia Surakarta \\ ${ }^{1}$ Jl. Slamet Riyadi No. 361 Windan, Makamhaji, Kartasura, Sukoharjo, Indonesia \\ 1 agusprazetya123@gmail.com
}

\begin{abstract}
In this era of the Covid-19 pandemic, students are getting used to online learning or daring. In supporting online teaching and learning activities, electronic modules have been developed so that the learning system can run in two directions and be more interesting. For this reason, this study aims to (1) Design and implement the development of electronic modules based on learning projects in Web programming courses at ITB AAS Indonesia. (2) To find out student responses to the development of project-based emodules based on Web programming courses at ITB AAS Indonesia. This study uses research and development methods. with the development of the ADDIE model. To determine student responses to the electronic module, the researcher uses questionnaires. The results of the study show that: 1) The results of the design and implementation of e-modules that have been developed on web programming courses that use learning project-based learning models can be applied. 2) The results of the percentage of students who gave a very good response really good were $58,1 \%$, good $22,5 \% \%$, sufficientt $19,4 \%$ and there were no students who gave less, or very less responses..
\end{abstract}

Keywords : Electronic Module, Project Based Learning Model, Web Programming

\section{INTRODUCTION}

In this era of the Covid-19 pandemic, the learning system is still done by online. Lecturers must be able to master technology and start developing electronic modules to deliver the learning materials, therefore the learning system can be interactive and interesting. Many obstacles are often encountered in the process of making e-modules and the system to be used. Several things must be considered such as the accessibility, flexibility, and effectiveness. ITB AAS Indonesia is one of the institutes that uses e-learning as a distance learning tool. Lecturers must have an electronic module which is then uploaded to the e-learning. Electronic modules as digital teaching materials must meet eligibility qualifications in terms of validity, applicability, practicality, presentation, and legibility as teaching materials. The use of electronic module can make the students learn independently and can access materials wherever they are, it also will change the views of students to read and consume interactively and make them comfortable, where the printed modules have images, narratives, and graphics but emodules can contain various features such as audio, music, animation, and video.

Learning modules must be able to help students achieve the expected basic competency standards. To design learning materials, there are five categories of capabilities that can be learned by students, namely (1) verbal information, (2) intellectual skills, (3) cognitive strategies, (4) attitudes, and (5) motor skills. These five things are important in designing learning because they can make students more interested in learning. The existence of emodules can support and complement the teacher's role as the only source of information for students. E-module is an ICT-based module, which is more interactive in nature, makes it easier to navigate, allows presenting images, audio, video and animation and is equipped with formative tests or quizzes that allow immediate automatic feedback . Thus, emodules must be made clear and attractive so that students can more easily capture information. At ITB AAS Indonesia, especially in web programming courses, uses a project-based learning model.

Project-based learning is a learning model that involves a project in the learning process. It is a dynamic learning approach in which students are able to actively explore the real world's problem, get challenged, and get a deeper understanding about an issue . Project-based learning is a form of constructivist and collaborative learning in which the learning process using student-centered learning, which allows students to work together to solve problems, and learn from one another along to build their knowledge . The project can be an individual or group project. The project contains problem-based tasks given to students as a first step in gathering new knowledge based on their experience in real activities, and requires students to solve problems, make decisions, and provide opportunities for students to work independently or in groups. The end result of the project work is a product that can be in the form of a written report or presentation. From the explanation above, project based learning is needed in the development of e-modules so that the distance learning process can run effectively. The author uses several research results from previous researchers as a reference in making this article, namely; Santyasa (2007), Winaya et al. (2016), and Veronika et al, (2016). The similarity between this research and this research is that they both study web programming EModules that use a project based learning model, but the difference is in the platform used. Previous research used the Moodle and Schoology platforms. Meanwhile, this study used an e-learning platform.

\section{RESEARCH METHODS}

This research is a type of research and development or in English is Research and Development (R\&D). This study aims to develop an e-module for web programming courses at ITB AAS Indonesia. Development Research and Development (R\&D) is a research method used to produce 
International Journal of Computer and Information System (IJCIS)

Peer Reviewed - International Journal

Vol : Vol. 02, Issue 03, August 2021

e-ISSN : 2745-9659

https://ijcis.net/index.php/ijcis/index

certain products, and test the effectiveness of these products . This research uses ADDIE model to develop the electronic module with project-based learning. This model is systematically to overcome learning problems related to learning resources that are in accordance with the needs and characteristics of learners.

This model consists of: a) Analysis, at this stage an analysis of the availability of learning resources and student characteristics is carried out. b) Design, at this stage a review and improvement is carried out if there is a design discrepancy between the needs of users and developers. c) Development, this is the stage of preparing materials and assignments. The researcher gave a questionnaire that was used to measure the suitability of the material, the language used, and the readability of the resulting e-module. Then, at the development stage, the design of the e-module software system began to be compiled and translated into e-learning. d) Implementation, at this stage an e-module trial is conducted for students. The trials included material expert testing, design expert testing, learning media expert testing as well as individual trials, small group trials and field trials. e) Evaluation, at this stage evaluation of data from trial activities is carried out. The researcher gave a questionnaire to students about the suitability of the material in the module, the suitability of the language used in the e-module, the readability of the e-module, and the presentation. Furthermore, based on suggestions or comments written in the questionnaire, improvements were made to the e-module.

\section{RESULT AND ANALYSIS}

The results of the e-module display using the project based learning model are as figure 3.1

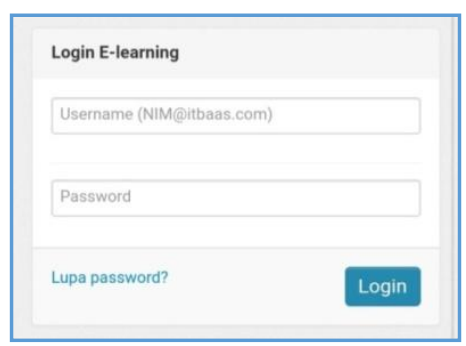

Figure 3.1 E-Module Login Page Display

The picture above shows that on the login page students are asked to enter a username and password to access the emodule in e-learning, on the figure 3.2

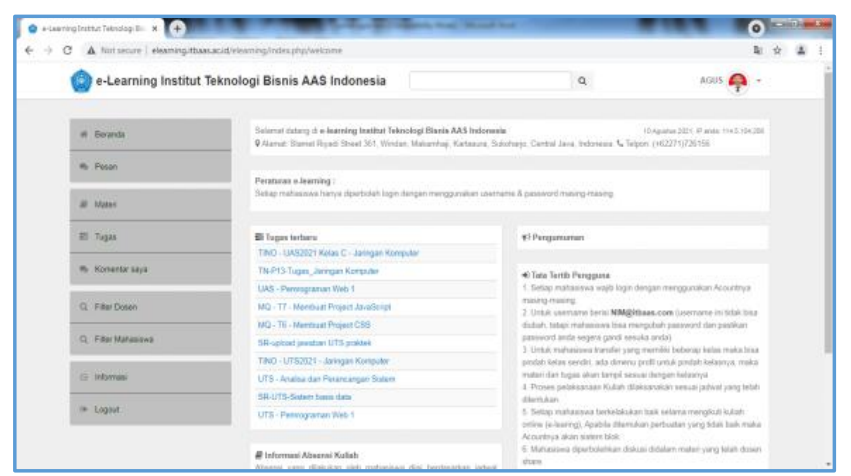

Figure 3.2 Main Page Display
The picture above shows the main page display for students. The students can view the latest information provided by the lecturer on the figure 3.3

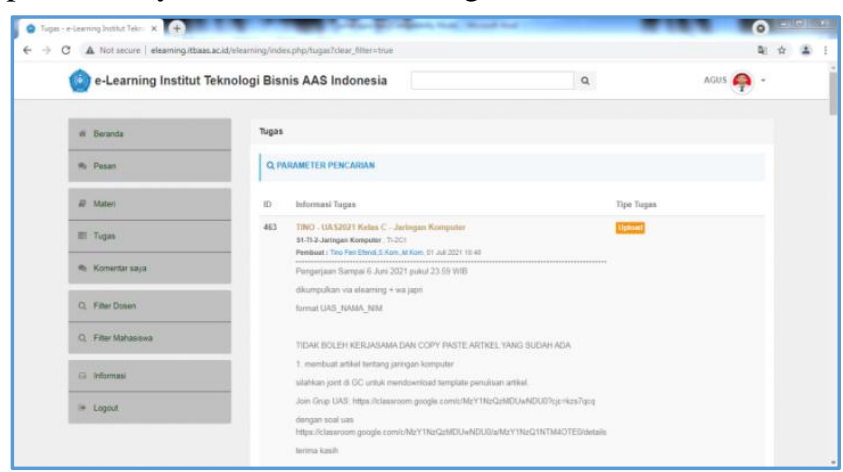

Figure 3.3 Learning Activity Page Display

The picture above shows the display of the student learning activity page. So, students can access the material provided by the lecturer on the figure 3.4

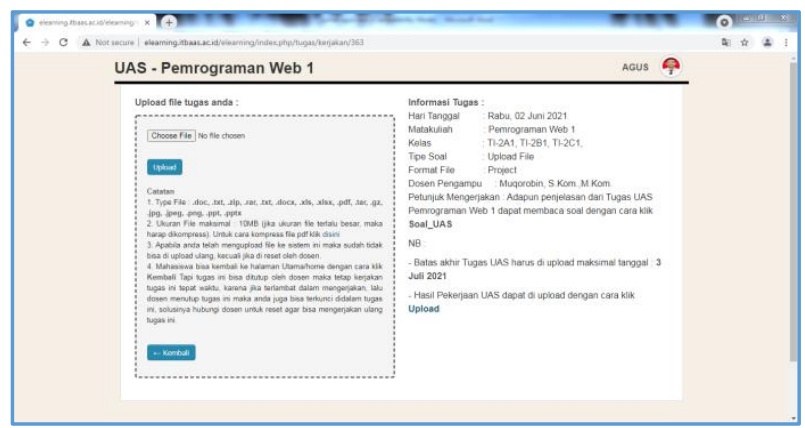

Figure 3.4 Project Page Display

Figure 3.4 shows the project development page that will be done by students. They can see the latest tasks or projects that need to be done. Before the electronic module in e-learning is used by students, the application will be tested first to ensure that the application is running properly and there are no errors. The tests carried out are: a) the material expert test is carried out by a lecturer in charge of the subject. Based on the data calculated from the questionnaire, the result is 1 if it is converted to the criteria table for the validation level of the Expert Test which is in the "Very High" criteria, therefore the e-module is declared suitable for use in lectures. b) The design expert test is carried out by a lecturer in charge of learning design. Based on the data calculated from the questionnaire, the result is 1 if it is converted to the criteria table for the validation level of the Expert Test which is in the "Very High" criteria, therefore the e-module is declared suitable for use in lectures. c) The media expert test is carried out by an informatics engineering lecturer. The things tested at this stage consist of several indicators such as the use of language and legibility, graphics, e-module display design, effectiveness, and media developed in the e-module. the criteria table for the validation level of the Expert Test is on the "Very High" criteria and is suitable for use in lectures. The e-module product has a "High" level of achievement, but the suggestions given by media experts are taken into 
International Journal of Computer and Information System (IJCIS)

Peer Reviewed - International Journal

Vol : Vol. 02, Issue 03, August 2021

e-ISSN : 2745-9659

https://ijcis.net/index.php/ijcis/index

consideration for the perfection of the e-module. The revisions made to the e-module is by providing progress on the project. d) The results of student responses involving 31 students who have previously used e-modules in e-learning, with SPSS type 25 analysis calculations can be seen in table 1 below.

Table 4.1The Result of Student Response

Based on the table above, it can be concluded that the results of the study indicate that student responses to emodules in web programming courses based on projectbased learning are very good and e-modules are feasible to use. The results of the development of e-modules in the web programmer course based on project based learning have the aim of increasing student independence and are expected to improve understanding of the material in the web programmer course. They are able to review their practices during learning by interaction and exchange experience ${ }^{1}$. Based on the results of the questionnaire, it can be seen that the e-module is very good so that it can help students complete the projects given by the lecturer. The results of the research on the network operating system emodule are in line with research from Winaya et al. (2016), which are both feasible and effective to use in learning. This e-module underwent a series of trials first which was then revised until it was finally used. So it can be concluded that the feasibility and effectiveness of an e-module can be achieved if it has passed a number of tests first. In its implementation, this project-based e-module is also equipped with a discussion feature that allows discussion between students and lecturers as well as with other students. This will create an interactive learning atmosphere. This is in accordance with the opinion of Veronika et al, (2016) that in its implementation an emodule is equipped with a discussion feature that allows discussion between students and teachers and between students.

\section{IV.CONCLUSION}

The results of the study show that: 1) the results of the design and implementation of e-modules that have been developed in web programming courses that use the project based learning model are feasible to use. 2) The result of the percentage of students who gave a very good response was $58.1 \%$, either $22.5 \%, 19.4 \%$ was sufficient and there were no students who gave poor or very poor responses. During the e-module implementation test, the researcher did not find any significant obstacles. The implementation process can run smoothly because of the support from all parties.

\begin{tabular}{lcc}
\hline Category & Percentage (\%) & $\begin{array}{c}\text { Number of } \\
\text { Respondents }\end{array}$ \\
\hline Very good & $58,1 \%$ & 18 \\
Good & $22,5 \%$ & 7 \\
sufficientt & $19,4 \%$ & 6 \\
less & $0 \%$ & 0 \\
Very less & $0 \%$ & 0 \\
\hline
\end{tabular}

\section{SUGGESTIONS}

Based on the results of the research above, there are several things that can be taken into consideration for follow-up. 1) Project-based learning-based e-module products need to be developed or added to student progress. Therefore, it is open for other researchers to study further the measurement of final learning outcomes or progress. 2) The developed e-module product can be used as classroom action research (CAR) for other researchers.

\section{REFERENCES}

[1] Almulla, Mohammed Abdullatif. "The Effectiveness of the Project-Based Learning (PBL) Approach as a Way to Engage Students in Learning." SAGE Open 10, no. 3 (2020). https://doi.org/10.1177/21582440 20938702.

[2] Astalini, Darmaji, Wawan Kurniawan, Khairul Anwar, and Dwi Agus Kurniawan. "Effectiveness of Using E-Module and e-Assessment." International Journal of Interactive Mobile Technologies 13, no. 9 (2019): 21-39. https://doi.org/10.3991/ijim.v13i09.11016.

[3] Rini, Titis, and Puri Cholifah. "Electronic Module With Project Based Learning (PjBL): Innovation Of Digital Learning Product On 4.0 Era." Edcomtech Jurnal Kajian Teknologi Pendidikan 5, no. 2 (2020): 155-61.https://doi.org/10.17977/um039v5i22020p155

[4] Sugiyono. "Metode Penelitian Pendidikan Pendekatan Kuantitaif, Kualitatif, Dan R\&DSugiyono. 2013. 'Metode Penelitian Pendidikan Pendekatan Kuantitaif, Kualitatif, Dan R\&D.' Metode Penelitian Pendidikan Pendekatan Kuantitaif, Kualitatif, Dan R\&D. Https://Doi.Org/10.1." Metode Penelitian Pendidikan Pendekatan Kuantitaif, Kualitatif, Dan R\&D, 2013.

[5] Sumarni, W., S. Wardani, S. Sudarmin, and D. N. Gupitasari. "Project Based Learning (PBL) to Improve Psychomotoric Skills: A Classroom Action Research.” Jurnal Pendidikan IPA Indonesia 5, no. 2 (2016): 157-63. https://doi.org/10.15294/jpii.v5i2.4402.

[6] Susilawati, Aay, Hernani Hernani, and Parlindungan Sinaga. "The Application of Project-Based Learning Using Mind Maps To Improve Students' Environmental Attitudes Towards Waste Management in Junior High Schools." International Journal of Education 9, no. 2 (2017): 120. https://doi.org/10.17509/ije.v9i2.5466.

[7] Vanorika, Kadek Benny, Gede Saindra Santyadiputra, and I Gede Partha Sindu. "Pengembangan E-Modul Berbasis Project Based Learning Pada Mata Pelajaran Sistem Operasi Jaringan Kelas Xi Di Smk Negeri 3 Singaraja." Jurnal Pendidikan Teknologi Dan 
International Journal of Computer and Information System (IJCIS)

Peer Reviewed - International Journal

Vol : Vol. 02, Issue 03, August 2021

e-ISSN : 2745-9659

https://ijcis.net/index.php/ijcis/index

Kejuruan 13, no. 2 (2016): 212-24.

https://doi.org/10.23887/jptk-undiksha.v13i2.8529.

[8] Whatley, Janice. "Evaluation of a Team Project Based Learning Module for Developing Employability Skills." Issues in Informing Science and Information Technology, 2012. https://doi.org/10.28945/1605.

[9] Winaya, I Kadek Adi, I Gede Mahendra Darmawiguna, and I Gede Partha Sindu. "Pengembangan E-Modul Berbasis Project Based Learning Pada Mata Pelajaran Pemrograman Web Kelas X Di Smk Negeri 3 Singaraja." Jurnal Pendidikan Teknologi Dan Kejuruan 13, no. 2 (2016). https://doi.org/10.23887/jptk.v13i2.8527. 